(c) American Dairy Science Association, 2003.

\title{
Effect of Dietary Cobalt Supplementation on Cobalt Metabolism and Performance of Dairy Cattle
}

\author{
R. L. Kincaid, ${ }^{\star 1}$ L. E. Lefebvre, ${ }^{\star}$ J. D. Cronrath, ${ }^{\star}$ M. T. Socha, $†$ and A. B. Johnson† \\ *Animal Sciences Department, Washington State University, Pullman 99164-6351 \\ †Zinpro Corp., Eden Prairie, MN 55344-7298
}

\begin{abstract}
Three studies were conducted with dairy cattle fed diets with added Co. The first study examined cow age and added dietary Co on Co in liver and blood. Nonpregnant, nonlactating Holstein cows were blocked by age (2.5 or $6.5 \mathrm{yr}$ ) and assigned to either a control diet or a diet supplemented with $9 \mathrm{mg}$ Co per day. The Co concentration of liver, taken on $d 60$, was not affected by dietary Co but was higher in the younger cows. The cytosolic fraction of liver contained the most $\mathrm{Co}$, and the subcellular distribution of Co was not affected by total Co in liver. In a second study, Holstein cows were assigned to one of three treatments of dietary Co from $21 \mathrm{~d}$ prepartum until $120 \mathrm{~d}$ postpartum. There was an interaction of time $\times$ treatment $\times$ parity such that milk yield response to Co supplementation differed between multiparous cows and primiparous cows. Supplemental Co did not increase Co in serum, colostrum, milk, or liver. Primiparous cows secreted colostrum and milk with higher Co concentrations than did multiparous cows. Likewise, serum $\mathrm{B}_{12}$ levels were higher in primiparous than multiparous cows and declined with increasing days in milk (DIM). Serum Co also decreased from 7 to 120 DIM. In a final study, a Co supplement in the starter diet did not affect Co in serum or liver of young calves. In conclusion, supplemental dietary Co did not affect secretion of Co in milk, tissue retention, or subcellular distribution of Co within the liver. Primiparous and multiparous cows differed in their milk yield response to dietary Co supplementation.
\end{abstract}

(Key words: cobalt, cow, calf, vitamin $\mathrm{B}_{12}$ )

Abbreviation key: AAS = atomic absorption spectrophotometry, $\mathbf{E E}=$ ether extract.

Received August 12, 2002.

Accepted October 26, 2002.

Corresponding author: R. L. Kincaid; e-mail: rkincaid@wsu.edu.

${ }^{1}$ Appreciation is expressed to Zinpro Corp., Eden Prairie, MN, for partial funding support for this study. The use of trade names and/or products in this publication does not imply endorsement or criticism of those products.

\section{INTRODUCTION}

Cobalt is an essential trace element in ruminant diets for the production of vitamin $B_{12}$ by the rumen microbes to meet the vitamin $\mathrm{B}_{12}$ requirements of both the ruminal bacteria and the host animal (McDowell, 1992). The NRC (2001) lists the dietary requirement of dairy cattle for Co as $0.11 \mathrm{mg} / \mathrm{kg}$; however, ruminal synthesis of $\mathrm{B}_{12}$ increased nearly 20 -fold in sheep when dietary Co was increased from 0.1 to $0.5 \mathrm{mg} / \mathrm{kg}$ (Mills, 1981). Furthermore, Kawashima et al. (1997) found the concentrations of vitamin $\mathrm{B}_{12}$ in serum and liver of sheep were increased until dietary Co was $40 \mathrm{mg} / \mathrm{kg}$. In addition, Allen (1986) reported increased cellulose digestibility in vitro of diets containing $10 \mathrm{mg} / \mathrm{kg}$ added Co.

In the ruminant, the efficiency of production of vitamin $\mathrm{B}_{12}$ (cobalamin) from $\mathrm{Co}$ is low, only about $3 \%$; however, efficiency increases to about $13 \%$ when Co intake is low (Smith and Marston, 1970). The relative production of cobalamin and the cobalamin analogs, which have no $\mathrm{B}_{12}$ activity, is affected by the diet (Dryden and Hartman, 1971; Sutton and Elliot, 1972). In general, diets that are largely composed of roughages tend to promote greater production of cobalamin, and diets containing larger amounts of concentrates tend to reduce cobalamin production and to lower the ratio of cobalamin to the various analogues of vitamin $\mathrm{B}_{12}$ (Sutton and Elliot, 1972). Elliot et al. (1979) established that vitamin $\mathrm{B}_{12}$ in blood is reduced in cows during early lactation.

Relatively little is known about Co metabolism in cattle. Although some nonvitamin $\mathrm{B}_{12}$ roles for Co may exist, none have been clearly elucidated. Elemental Co is absorbed through the intestinal tract (Wapnir, 1990) and transported in blood to various tissues (Underwood and Suttle, 1999). The liver contains the highest concentration of Co within tissues and is considered the main storage site (Underwood and Suttle, 1999). Thus, the objectives of the current studies were to determine if supplemental dietary Co affected tissue retention of $\mathrm{Co}$, the subcellular distribution of Co within liver, milk production of cows, and growth of young calves. 
Table 1. Chemical composition of the diet components fed to nonlactating Holstein cows for $60 \mathrm{~d}$ (Study 1$){ }^{1}$

\begin{tabular}{lllc}
\hline & $\begin{array}{l}\text { Control } \\
\text { concentrate }\end{array}$ & $\begin{array}{l}\text { Co-supplemented } \\
\text { concentrate }\end{array}$ & Pea hay \\
\hline Dry matter, \% & 93.4 & 93.8 & 95.1 \\
Crude protein, \% & 12.6 & 12.9 & 9.0 \\
NDF, \% & 17.3 & 17.9 & 47.3 \\
ADF, \% & 2.8 & 3.3 & 33.0 \\
Calcium, \% & 0.44 & 0.53 & 0.93 \\
Phosphorus, \% & 0.35 & 0.34 & 0.22 \\
Cobalt, mg/kg & 1.0 & 3.4 & 0.4 \\
\hline
\end{tabular}

${ }^{1}$ Dry matter basis.

\section{MATERIALS AND METHODS}

Three studies were conducted to evaluate Co supplementation effects on Co metabolism in dairy cattle. The protocols were approved by the Institutional Animal Care and Use Committee of Washington State University.

Study 1. Nonpregnant, nonlactating Holstein cows $(\mathrm{n}=8)$ were blocked by age (2.5 yr, range 2 to 3 and $6.5 \mathrm{yr}$, range 5 to 7 ) and then randomly assigned to one of two treatment groups. Cows receiving each treatment were housed together and group fed. Treatments were a pelleted concentrate that was fed to supply either 3.6 (control) or $12.4 \mathrm{mg}$ (supplemented) Co daily. The concentrate consisted of $87.5 \%$ ground corn, $9.2 \%$ soybean meal $(44 \% \mathrm{CP}), 1.24 \%$ limestone, $1.16 \%$ trace mineral premix, $0.56 \%$ animal fat, $0.22 \%$ Se premix $(200 \mathrm{mg} / \mathrm{kg} \mathrm{Se}), 0.03 \%$ vitamin A premix $(30,000 \mathrm{IU} / \mathrm{g})$, and $0.05 \%$ cellulose gum. The trace mineral premix contained $69.17 \%$ iodized salt, $10.91 \% \mathrm{Zn}$ methionine (10\% Zn, Zinpro Corp., Eden Prairie, MN), 5.33\% Zn sulfate $(36.4 \% \mathrm{Zn}), 7.58 \% \mathrm{Mn}$ methionine (8\% Mn, Zinpro Corp.), $1.7 \% \mathrm{Mn}$ oxide ( $72 \% \mathrm{Mn}$ ), $3.79 \% \mathrm{Cu}$ lysine $(10 \% \mathrm{Cu}$, Zinpro Corp.), and $1.52 \% \mathrm{Cu}$ sulfate $(25 \% \mathrm{Cu})$. In the premix with added $\mathrm{Co}, 1.89 \%$ Co glucoheptonate $(2.5 \% \mathrm{Co})$ replaced an equal amount of iodized salt. The concentrate was fed once daily at the rate of $3.6 \mathrm{~kg} / \mathrm{cow}$ per day. In addition, pea hay $(0.4 \mathrm{mg} / \mathrm{kg}$ cobalt $)$ and water were available free choice at all times. The chemical composition of the concentrate and hay is given in Table 1. Cows were fed their treatment diets for $60 \mathrm{~d}$ before slaughter.

Study 2. Holstein cows ( $\mathrm{n}=36 ; 9$ primiparous and 27 multiparous cows), $21 \mathrm{~d}$ before their expected calving date, were assigned to prepartum diets of grass hay provided free choice and individually fed $3.3 \mathrm{~kg}$ (DM basis) of concentrate per day to provide treatments designated as low, medium, and high intakes of Co. The concentrate was composed of $81.2 \%$ ground corn, $11.9 \%$ soybean meal $(44 \% \mathrm{CP}), 5 \%$ molasses, $1 \%$ trace mineral
Table 2. Trace mineral premixes for dry cow concentrates (Study 2).

\begin{tabular}{lccc}
\hline Ingredient & $\begin{array}{c}\text { Low Co } \\
\text { Salt \#1 }\end{array}$ & $\begin{array}{c}\text { Med Co } \\
\text { Salt \#2 }\end{array}$ & $\begin{array}{c}\text { High Co } \\
\text { Salt \#3 }\end{array}$ \\
\cline { 2 - 4 } & \multicolumn{4}{c}{ \% of salt mix } \\
\cline { 2 - 4 } Iodized salt & 69.28 & 68.33 & 67.38 \\
Zn methionine & 10.90 & 10.90 & 10.90 \\
Zn sulfate $^{2}$ & 5.34 & 5.34 & 5.34 \\
Cu lysine & 3.80 & 3.80 & 3.80 \\
Cu sulfate $^{3}$ & 1.52 & 1.52 & 1.52 \\
Mn methionine $^{5}$ & 7.50 & 7.50 & 7.50 \\
Mn oxide $^{6}$ & 1.66 & 1.66 & 1.66 \\
Co GH $^{7}$ & 0 & 0.95 & 1.90 \\
& 100 & 100 & 100 \\
\hline
\end{tabular}

\footnotetext{
${ }^{1} 10 \% \mathrm{Zn}$ as Zn methionine (Zinpro Corp., Eden Prairie, MN).

${ }^{2} 36.4 \% \mathrm{Zn}$ in $\mathrm{Zn}$ sulfate.

${ }^{3} 10 \% \mathrm{Cu}$ in $\mathrm{Cu}$ lysine (Zinpro Corp.).

${ }^{4} 25 \% \mathrm{Cu}$ in $\mathrm{Cu}$ sulfate.

${ }^{5} 8 \% \mathrm{Mn}$ in $\mathrm{Mn}$ methionine (Zinpro Corp.).

${ }^{6} 72 \% \mathrm{Mn}$ in $\mathrm{Mn}$ oxide.

${ }^{7} 2.5 \%$ Co in Co glucoheptonate (Zinpro Corp.).
}

premix (Table 2), $0.5 \%$ iodized salt, $0.1 \%$ vitamin $\mathrm{D}$ premix (8810 IU/g), $0.025 \%$ vitamin A premix $(30,000$ $\mathrm{IU} / \mathrm{g}), 0.2 \%$ Se premix (200 $\mathrm{mg} / \mathrm{kg}$ Se as $\mathrm{Na}$ selenite), and $0.05 \%$ cellulose gum. Fed at $3.3 \mathrm{~kg} / \mathrm{d}$, the concentrate supplied the dry cows with 0,12 , and $25 \mathrm{mg}$ of Co per day. Based upon chemical analysis of the hay and concentrates (Table 3 ) and an estimated hay intake of $9.1 \mathrm{~kg} / \mathrm{d}$, prepartum intakes of Co were $3.1,13.8$, and $23.6 \mathrm{mg} / \mathrm{d}$ for the dry cows.

Subsequent to parturition, cows remained assigned to their respective treatments of low, medium, and high Co treatments until 120 DIM. The dietary concentrations of Co for the three treatments were $0.37,0.68$, and $1.26 \mathrm{mg} / \mathrm{kg}$ Co. The lactating cows were individually fed a TMR (Table 4) via Calan feeding gates, and daily feed intakes were measured. The chemical composition of

Table 3. Chemical composition of concentrates and hay fed to dry cows (Study 2). ${ }^{1}$

\begin{tabular}{lcccc}
\hline & \multicolumn{3}{c}{ Concentrates } \\
\cline { 2 - 4 } & Low Co & Medium Co & High Co & Hay \\
\hline $\mathrm{CP}, \%$ & 13.5 & 13.8 & 13.3 & 10.6 \\
$\mathrm{NDF}, \%$ & 12.6 & 12.2 & 12.0 & 56.2 \\
$\mathrm{ADF}, \%$ & 2.23 & 1.86 & 1.61 & 34.6 \\
$\mathrm{Ether}$ extract, \% & 0.56 & 0.58 & 0.50 & 1.40 \\
$\mathrm{Ca}, \%$ & 0.16 & 0.18 & 0.17 & 0.42 \\
$\mathrm{P}, \%$ & 0.31 & 0.31 & 0.31 & 0.26 \\
$\mathrm{~K}, \%$ & 0.60 & 0.63 & 0.62 & 1.79 \\
$\mathrm{Na}, \%$ & 0.57 & 0.54 & 0.56 & 0.46 \\
$\mathrm{Co}, \mathrm{mg} / \mathrm{kg}$ & 0.51 & 3.74 & 6.71 & 0.16 \\
$\mathrm{Zn}, \mathrm{mg} / \mathrm{kg}$ & 304 & 328 & 357 & 39.5 \\
$\mathrm{Cu}, \mathrm{mg} / \mathrm{kg}$ & 53 & 60 & 63 & 5.5 \\
$\mathrm{Fe}, \mathrm{mg} / \mathrm{kg}$ & 118 & 113 & 93 & 150 \\
$\mathrm{Mn}, \mathrm{mg} / \mathrm{kg}$ & 92 & 94 & 103 & 27 \\
\hline
\end{tabular}

${ }^{1}$ Dry matter basis. 
Table 4. Composition of total mixed rations for lactating cows (Study 2).

\begin{tabular}{lc}
\hline Ingredient & $\%, \mathrm{DM}$ basis \\
\hline Alfalfa silage & 27.08 \\
Alfalfa hay $^{1}$ & 23.70 \\
Concentrate $^{1}$ & 31.9 \\
Wheat mill run & 6.94 \\
Cottonseeds, whole & 10.38 \\
& 100 \\
\hline
\end{tabular}

${ }^{1}$ The ingredient composition of the concentrate was $84.175 \%$ corn, $7.89 \%$ peas, $2.63 \%$ soybean meal $(44 \% \mathrm{CP}), 2.5 \%$ molasses, $1.58 \%$ limestone, $1.5 \% \mathrm{Na}$ bicarbonate, $0.5 \%$ iodized salt, $0.5 \%$ trace mineral premix (the trace mineral premixed contained $0,1.55$, and $3.1 \%$ Co glucoheptonate; other ingredients were $1.3 \% \mathrm{Cu}$ sulfate, $3.24 \% \mathrm{Cu}$ lysine, $1.41 \% \mathrm{Mn}$ oxide, $6.47 \% \mathrm{Mn}$ methionine, $9.4 \% \mathrm{Zn}$ methionine, $4.56 \% \mathrm{Zn}$ sulfate, and the remainder was iodized salt, 70.52 to $73.62 \%), 0.5 \%$ animal fat, $0.4 \% \mathrm{Mg}$ oxide, $0.025 \%$ vitamin A premix $(30,000 \mathrm{IU} / \mathrm{g}), 0.05 \%$ vitamin D premix $(8810 \mathrm{IU} / \mathrm{g}), 0.2 \%$ Se premix (200 mg/kg Se), and $0.05 \%$ cellulose gum.

the TMR is given in Table 5. Beginning at 90 DIM, all cows received injections of recombinant bovine somatotropin (Posilac 1 Step, Monsanto Co., St. Louis, MO) on 14-d intervals.

Study 3. Newborn female Holstein calves $(\mathrm{n}=18)$ were assigned to receive either a complete textured starter $(0.63 \mathrm{mg} / \mathrm{kg} \mathrm{Co})$ or starter with added Co (1.34 $\mathrm{mg} / \mathrm{kg} \mathrm{Co}$ ). The ingredient composition of the starter was $30.2 \%$ steam-rolled barley, $32.2 \%$ ground corn, $15.27 \%$ alfalfa pellets, $15.1 \%$ soybean meal $(44 \% \mathrm{CP})$, $4.24 \%$ molasses, $0.57 \%$ iodized salt, $0.56 \%$ animal fat, $0.28 \%$ trace mineral premix, $0.11 \%$ pellet binder, 0.11 $\%$ Se premix (200 mg/kg Se), $0.05 \%$ vitamin A premix (30,000 IU/g), $0.03 \%$ vitamin D premix ( $8810 \mathrm{IU} / \mathrm{g})$, and $0.03 \%$ vitamin $\mathrm{E}$ premix (dl-alpha tocopheryl acetate, $500 \mathrm{IU} / \mathrm{g})$. The trace mineral premixes contained $73.62 \%$ iodized salt, $1.3 \%$ copper sulfate $(25 \% \mathrm{Cu})$,

Table 5. Chemical composition of TMR for lactating cows ${ }^{1,2}$ (Study 2).

\begin{tabular}{lccc}
\hline & \multicolumn{3}{c}{ Treatment } \\
\cline { 2 - 4 } & Low Co & Medium Co & High Co \\
\hline $\mathrm{CP}, \%$ & 18.0 & 18.3 & 18.0 \\
$\mathrm{NDF}, \%$ & 35.6 & 35.6 & 34.7 \\
$\mathrm{ADF}, \%$ & 22.2 & 21.6 & 21.4 \\
Ether extract, \% & 4.28 & 4.37 & 4.51 \\
$\mathrm{Ca}, \%$ & 0.67 & 0.70 & 0.67 \\
$\mathrm{P}, \%$ & 0.37 & 0.37 & 0.37 \\
$\mathrm{~K}, \%$ & 1.00 & 1.08 & 0.98 \\
$\mathrm{Na}, \%$ & 0.15 & 0.17 & 0.17 \\
$\mathrm{Co}, \mathrm{mg} / \mathrm{kg}$ & 0.37 & 0.68 & 1.26 \\
$\mathrm{Zn}, \mathrm{mg} / \mathrm{kg}$ & 57.2 & 57.8 & 59.6 \\
$\mathrm{Cu}, \mathrm{mg} / \mathrm{kg}$ & 12.8 & 13.4 & 13.3 \\
$\mathrm{Fe}, \mathrm{mg} / \mathrm{kg}$ & 475 & 455 & 481 \\
$\mathrm{Mn}, \mathrm{mg} / \mathrm{kg}$ & 33.7 & 33.8 & 35.3 \\
\hline
\end{tabular}

${ }^{1}$ By analysis, DM basis.

${ }^{2} \mathrm{NE}_{\mathrm{L}} \mathrm{Mcal} / \mathrm{kg}=1.6$ (calculated from NRC, 2001).
$3.24 \%$ copper lysine ( $10 \% \mathrm{Cu}$, Zinpro Corp.), $1.41 \%$ manganese oxide $(72 \% \mathrm{Mn}), 6.47 \%$ manganese methionine (8\% Mn, Zinpro Corp.), $9.4 \%$ zinc methionine (10\% Zn, Zinpro Corp.), and $4.56 \%$ zinc sulfate $(36.4 \% \mathrm{Zn})$. In the trace mineral premix used in the Co-supplemented starter, $1.55 \%$ cobalt glucoheptonate $(2.5 \%$ Co, Zinpro Corp.) was substituted for an equal amount of iodized salt. Calves were individually housed in sheltered runs bedded with wood shavings. The chemical compositions of the starters were $17 \% \mathrm{CP}, 20 \% \mathrm{NDF}, 8.5 \% \mathrm{ADF}$, $0.87 \% \mathrm{Ca}, 0.32 \% \mathrm{P}, 36 \mathrm{mg} / \mathrm{kg} \mathrm{Zn}$, and $7.6 \mathrm{mg} / \mathrm{kg} \mathrm{Cu}$. In addition to the starter, calves were fed $2.27 \mathrm{~kg}$ of pooled milk twice daily ( 0500 and $1500 \mathrm{~h}$ ) during their first 4 wk and $1.14 \mathrm{~kg}$ milk twice daily for the subsequent 2 wk. Feed refusals were weighed back and fresh feed added once daily.

\section{Measures of Performance and Sampling}

Experiment 1. Blood samples were collected into heparinized and nonheparinized vacutainers on $\mathrm{d} 1,30$, and 60. Cows were humanely killed on $\mathrm{d} 60$, and samples were taken from the ventral lobe of the liver within 20 min after exsanguination. Liver samples were individually identified, refrigerated at $4{ }^{\circ} \mathrm{C}$ until the following day, then homogenized in three volumes of $0.1 \mathrm{M}$ ammonium acetate buffer ( $\mathrm{pH}$ 7.4). The liver homogenates were separated into subcellular components by differential centrifugation according to Chen et al. (1999).

Experiment 2. Daily DMI were recorded for lactating cows, and samples of the TMR were taken weekly and composited by month. Cow BW and condition scores were taken on $\mathrm{d}-21,-7,7,30,60,90$, and 120 relative to parturition. Blood samples were collected into heparinized and nonheparinized vacutainers on $d-21,-7$, $0,7,21$, and 120 . Immediately postpartum, a sample of colostrum was collected. Milk yields were recorded daily, and samples of a.m./p.m. milk were taken monthly for analysis via an infrared spectrophotometer (Bentley 2000; Bentley Instruments, Chaska, MN; AOAC, 1990) of major components by the regional DHIA laboratory (Burlington, WA). Samples of serum, whole blood, colostrum, and milk were frozen until analysis. Percutaneous liver biopsies were obtained under a local anesthesia (5 mg of Lidocaine and $50 \mathrm{mg}$ of Flunixine meglumine) at 120 DIM between the 9 th and 10th intercostal space using a 15 -cm Tru-Cut biopsy needle (Tranvenol Labs, Deerfield, IL). Biopsy specimens were transferred to a tared vial and reweighed. The samples were stored at $-30^{\circ} \mathrm{C}$ until analysis.

Experiment 3. Calves were weighed weekly on the same day each week. Feed samples were collected weekly and composited by month. Blood samples were 
collected via jugular venipuncture in both heparinized and nonheparinized vacutainers within the first $24 \mathrm{~h}$ of birth and again at the end of wk 6 and 12 . Hematocrit concentrations were determined on each sample, and a subsample was spun at $1875 \mathrm{~g}$ for 20 min to obtain serum. Whole blood and serum samples were then frozen at $-20^{\circ} \mathrm{C}$ to await further analysis. Liver samples were taken by biopsy (as described above) from each calf at 12 wk of age and frozen at $-20^{\circ} \mathrm{C}$ until analysis. Ruminal fluid samples from calves were also taken at $12 \mathrm{wk}$ of age using an esophageal tube, and $4 \mathrm{ml}$ of ruminal fluid was mixed with $1 \mathrm{ml}$ of $25 \%$ sodium metaphosphoric acid. Fluid was separated by centrifugation at $25,133 \times \mathrm{g}$ for $30 \mathrm{~min}$, and the supernates were kept refrigerated at $4^{\circ} \mathrm{C}$ until analyzed.

\section{Analyses}

Composite feed samples were dried $\left(60^{\circ} \mathrm{C}\right.$ for $\left.48 \mathrm{~h}\right)$, ground to pass a 2-mm screen (Wiley mill; Arthur H. Thomas Co., Philadelphia, PA), subsampled, then reground to pass through a $1-\mathrm{mm}$ screen, subsampled again, and stored at $-20^{\circ} \mathrm{C}$ until further analysis. Feed analysis consisted of $\mathrm{DM}$ at $100^{\circ} \mathrm{C}$ (AOAC, 1990), CP by an automated nitrogen analyzer (Leco FP-528), ether extract (EE) (AOAC, 1990), and NDF and ADF using an Ankom 200 Fiber Analyzer (Ankom Technologies, Fairfield, NY). Blood, liver, homogenates of liver, colostrum, and milk samples were analyzed for Co by neutron activation analysis $\left({ }^{60} \mathrm{Co}\right.$ with a half-life of $5.27 \mathrm{yr}$ using a multichannel analyzer) at the Washington State University's Nuclear Reactor Center. Copper, Ca, $\mathrm{Zn}, \mathrm{Cu}$, and $\mathrm{Fe}$ concentrations were determined by atomic absorption spectrophotometry (AAS; Robinson, 1975); K and Na by atomic emission spectrophotometry (Robinson, 1975); Mn by graphite furnace AAS (CHGA400, Perkin-Elmer, Norwalk, CT); Zn in liver samples taken via biopsy by neutron activation analysis; Co in feeds by AAS (University of Missouri-Columbia Experiment Station Chemical Labs); and P by colorimetry (AOAC, 1990). Milk fat and protein composition were done via infrared spectrophotometer (AOAC, 1990) at the regional DHIA laboratory. Glucose analysis was by a commercial kit (Sigma Chemical Co., St. Louis, MO) and NEFA were also done using a commercial kit (NEFA-C, Wako Chemical GmbH, Neuss, Germany). Vitamin $B_{12}$ analyses were by radioimmunoassay modified so proteins were denatured by heating samples in a boiling water bath for 10 min instead of incubating at $37^{\circ} \mathrm{C}$ for 30 min (USDA Human Nutrition Laboratory, Grand Forks, ND). Analysis of VFA in rumen fluid was by gas chromatography, using a Hewlett Packard 5890 chromatograph equipped with a C-5000 column (Alltech, Deerfield, IL) with an i.d. of $3.9 \mathrm{~mm}$. Settings included injector at 225 , detector at 250 , initial temperature of $120^{\circ} \mathrm{C}$, initial time of $12 \mathrm{~min}$, ramp rate of $5 \%$ $\mathrm{min}$, final temperature of $140^{\circ} \mathrm{C}$, final time of $5 \mathrm{~min}$, and helium flow of $2 \mathrm{ml} / \mathrm{min}$.

\section{Statistical Analysis}

Experiment 1. All data were statistically analyzed using the PROC MIXED procedure in SAS Version 8.0 (SAS, 2001). Data for Co concentrations in liver were found to be nonnormally distributed, so they were log transformed prior to analysis. All other data were normally distributed. The statistical model used in the serum and whole blood analyses was $Y=\mu+\alpha_{i}+\beta_{j}+$ $\delta_{k}+(\alpha \delta)_{i k}+(\beta \delta)_{j k}+(\alpha \beta)_{i j}+e_{i j k}$ where $\alpha_{i}=$ effect of diet, $\beta_{j}=$ age effect, $\delta_{k}=$ day effect, $(\alpha \delta)_{i k}=$ interaction effect between diet and day, $(\beta \delta)_{j k}=$ interaction effect between age and day, $(\alpha \beta)_{i j}=$ interaction effect between diet and age, and $e_{i j k}=$ experimental error. The statistical model used for the whole liver analysis was $Y=\mu+\alpha_{i}+\beta_{j}+$ $(\alpha \beta)_{i j}+e_{i j}$ where $\alpha_{i}=$ effect of diet, $\beta_{j}=$ age effect, $(\alpha \beta)_{i j}=$ interaction effect of diet and age, and $e_{i j}=$ experimental error. For the liver fractions, the statistical model used was $Y=\mu+\alpha_{i}+\beta_{j}+\delta_{k}+d_{l}\left(\alpha_{i} \beta_{j}\right)+(\alpha \delta)_{i k}+(\beta \delta)_{j k}+(\alpha \beta \delta)_{i j k}$ $+e_{i j k l}$ where $\alpha_{i}=$ effect of diet, $\beta_{j}=$ effect of age, $\delta_{k}=$ liver fraction, $d_{l}\left(\alpha_{i} \beta_{j}\right)=$ interaction effect of cow by cow within diet age subclass, $(\alpha \delta)_{i k}=$ interaction effect of diet and liver fraction, $(\beta \delta)_{j k}=$ interaction effect of age and liver fraction, $(\alpha \beta \delta)_{i j k}=$ interaction of diet, age, and liver fraction, and $e_{i j k l}=$ experimental error. Contrast statements were used to determine differences among fractions. Significance was declared at $P \leq 0.05$.

Experiment 2. Data were analyzed by general linear model of PROC MIXED procedures for a completely randomized design with repeated measures (SAS, 2001). The cows were blocked by parity according to expected calving date, and treatment assignments were rotated among cows within a block. The analysis of all time series data was performed using the model $\mathrm{Y}_{\mathrm{ijk}}=$ $\mu+\alpha_{\mathrm{i}}+\beta_{\mathrm{j}}+(\alpha \beta)_{\mathrm{ij}}+\mathrm{d}_{\mathrm{l}}\left(\alpha_{\mathrm{i}} \beta_{\mathrm{j}}\right)+\delta_{\mathrm{k}}+(\alpha \delta)_{\mathrm{ik}}+(\alpha \beta \delta)_{\mathrm{ijk}}+\mathrm{e}_{\mathrm{ijk}}$ where $\mathrm{Y}_{\mathrm{ijk}}=$ dependent variable, $\mu=$ dependent variable mean, $\alpha_{\mathrm{i}}=$ effect of treatment $_{\mathrm{i}}\left(\mathrm{i}=1\right.$ to 3 ), $\beta_{\mathrm{j}}=$ effect of parity $(\mathrm{j}=1$ or $>1),(\alpha \beta)_{\mathrm{ij}}=$ interaction effect between treatment and parity, $\mathrm{d}_{\mathrm{l}}\left(\alpha_{\mathrm{i}} \beta_{\mathrm{j}}\right)=$ random effect of cow, $\delta_{\mathrm{k}}=$ effect of sampling at week $\mathrm{k}_{\mathrm{k}}(\mathrm{k}=1$ to 17$),(\alpha \delta)_{\mathrm{ik}}=$ interaction effect between treatment and time, $(\alpha \beta \delta)_{\mathrm{ijk}}=$ interaction effect between treatment, parity, and week, and $\mathrm{e}_{\mathrm{ijk}}=$ residual error term. Milk yield for wk 1 and 2 was used as a covariant to calculate adjusted yields of milk and FCM when the data were separated according to parity of cows. Data for primiparous and multiparous cows also were compared by selected interaction contrasts. Statistical significance was declared at $P<0.05$. 
Table 6. Effect of cobalt supplementation on concentrations of cobalt, copper, and zinc in serum of nonlactating cows (Study 1).

\begin{tabular}{|c|c|c|c|c|}
\hline \multirow[b]{2}{*}{ Serum } & \multicolumn{3}{|c|}{ Length of supplementation, days } & \multirow[b]{2}{*}{$\mathrm{SE}$} \\
\hline & 0 & 30 & 60 & \\
\hline & \multicolumn{3}{|c|}{ Cobalt, $\mu \mathrm{g} / \mathrm{ml}$} & \multirow{3}{*}{0.05} \\
\hline Control & $0.25^{\mathrm{a}}$ & $0.23^{\mathrm{a}}$ & $0.26^{\mathrm{a}}$ & \\
\hline Added Co & $0.22^{\mathrm{a}}$ & $0.28^{\mathrm{a}}$ & $0.28^{\mathrm{a}}$ & \\
\hline Control & $0.93^{\mathrm{a}}$ & $0.65^{\mathrm{ab}}$ & $0.50^{\mathrm{b}}$ & \multirow[t]{2}{*}{0.10} \\
\hline Added Co & $0.83^{\mathrm{ab}}$ & $0.67^{\mathrm{ab}}$ & $0.69^{\mathrm{ab}}$ & \\
\hline Control & $0.72^{\mathrm{a}}$ & $0.98^{\mathrm{a}}$ & $0.79^{\mathrm{a}}$ & \multirow[t]{2}{*}{0.07} \\
\hline Added Co & $0.76^{\mathrm{a}}$ & $0.93^{\mathrm{a}}$ & $0.78^{\mathrm{a}}$ & \\
\hline
\end{tabular}

${ }^{\mathrm{ab}}$ Means within a mineral with different superscripts are different, $P<0.05$.

Experiment 3. All data were statistically analyzed using the PROC MIXED procedure in SAS Version 8.0 (SAS, 2001). All data were normally distributed. A random statement was used to help eliminate some of the variation caused by individual effect of animal. The statistical model used in the serum and whole blood analyses was $Y=\mu+\alpha_{i}+\beta_{j}+\delta_{k}+(\alpha \delta)_{i k}+(\beta \delta)_{j k}+e_{i j k}$ where $\alpha_{i}=$ effect of diet, $\beta_{j}=$ age of dam effect, $\delta_{k}=$ day effect, $(\alpha \delta)_{i k}=$ interaction effect between diet and day, $(\beta \delta)_{j k}=$ interaction effect between age of dam and day, and $e_{i j k}=$ experimental error. The statistical model used in liver analysis was $Y=\mu+\alpha_{i}+\beta_{j}+(\alpha \beta)_{i j}+e_{i j}$ where $\alpha_{i}=$ effect of diet, $\beta_{j}=$ age of dam effect, $(\alpha \beta)_{i j}=$ interaction effect of diet and age of dam, and $e_{i j}=$ experimental error. The statement model for VFA analysis was $\mathrm{Y}=$ $\mu+\alpha_{\mathrm{i}}+\mathrm{e}_{\mathrm{i}}$, where $\alpha_{\mathrm{i}}=$ effect of diet and $\mathrm{e}_{\mathrm{ij}}=$ experimental error.

\section{RESULTS AND DISCUSSION}

Experiment 1. Body weights of cows fed the control and Co-supplemented diets increased 20 and $78 \mathrm{~kg}$, respectively, during the 60 - $\mathrm{d}$ feeding period. Concentrations of Co in serum were not affected by dietary Co $(P$ $>0.05$; Table 6$)$ or age $(P>0.05)$; however, they increased with time $(P<0.05)$. No interactions were detected between treatment and sampling date $(P>0.05)$ or between age and sampling date $(P>0.05)$. Reported values for Co in serum vary markedly (Young, 1979); however, concentrations above $0.09 \mathrm{mg} / \mathrm{kg}$ indicate Co sufficiency (Puls, 1988). Cobalt concentrations in serum were about $0.02 \mathrm{mg} / \mathrm{kg}$ greater than for Co in whole blood (values not shown). Cobalt concentrations in liver were similar between treatment groups $(P>0.05$; Figure 1); thus, supplemental dietary Co did not increase Co storage in the liver. The values of Co in liver were within the sufficient range for cattle (Puls, 1988). However, age significantly $(P<0.01)$ affected the Co concen-

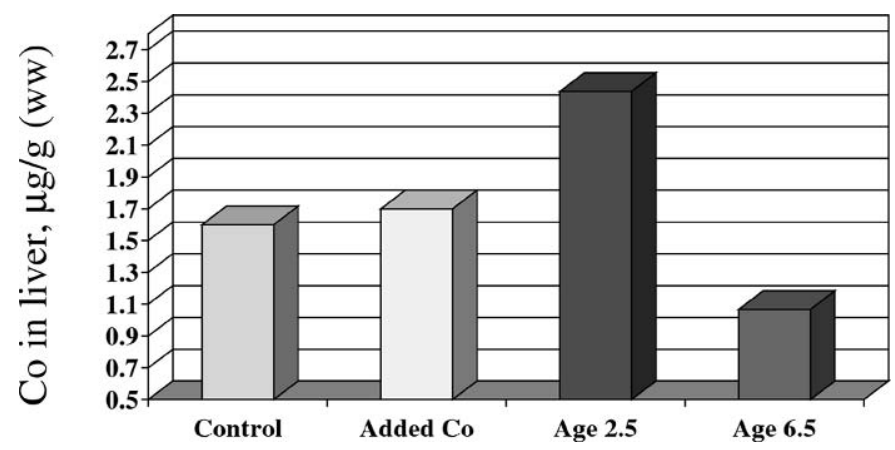

Figure 1. Effect of added dietary cobalt and age of cow on the concentration of cobalt in liver (wet wt), study $1 . \mathrm{SE}=0.17$.

tration of the liver with the younger cows having more than twice the concentration of Co in liver compared with older cows (Figure 1).

Concentrations of $\mathrm{Co}$ in serum and liver were significantly $(P<0.05)$ correlated $(\mathrm{r}=0.74)$. Due to similar serum Co values but much lower concentrations of Co in liver of older cows, concentrations of Co in liver and serum were more highly correlated within age group ( $\mathrm{r}$ $=0.92$ for the younger cows and $r=0.97$ for the older cows). Cobalt concentrations in whole blood were also correlated with liver $\mathrm{Co}(\mathrm{r}=0.77)$ with much stronger correlations within age group $(r=0.98$ for the younger cows and $r=0.97$ for older cows).

The percent distribution of Co among the cellular fractions of the liver (Figure 2) did not differ $(P>0.05)$ between the two treatments or age groups; thus, the greater amount of Co within liver of the younger cows was proportionately distributed among all subcellular fractions. The Co content was greatest in the cytosolic fraction, intermediate in the mitochondrial, microsomal, and lysosomal fractions, and least in the nuclear

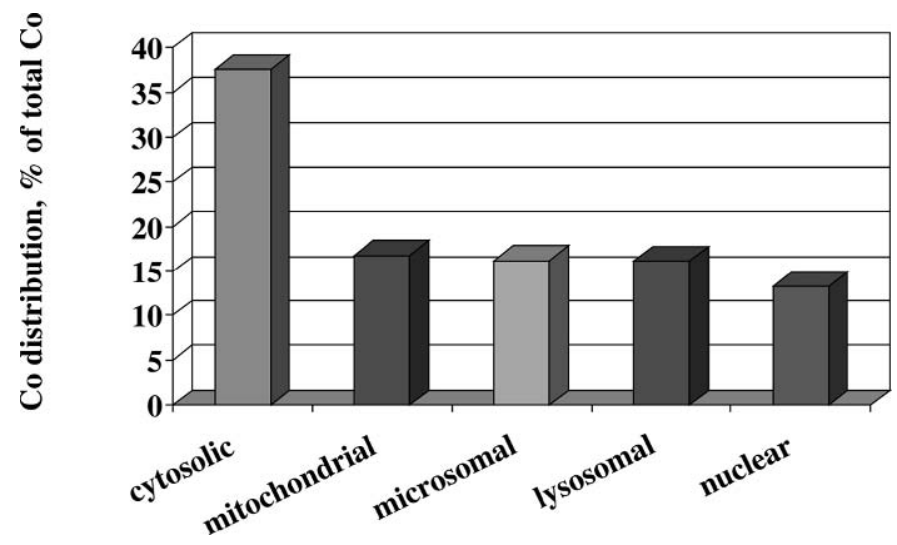

Figure 2. Percent distribution of cobalt within subcellular fractions of bovine liver, study 1 . SE $=0.05$. 
Table 7. Effect of dietary cobalt supplementation on body weight and condition score, feed intake, and yield of milk and milk components in lactating dairy cows (LSM, Study 2).

\begin{tabular}{|c|c|c|c|c|c|c|c|c|c|}
\hline \multirow[b]{2}{*}{ Measure } & \multicolumn{3}{|c|}{ Treatment } & \multirow[b]{2}{*}{$\mathrm{SE}$} & \multicolumn{5}{|c|}{$\begin{array}{l}\text { Type II SS } P>F \text { for } \\
\text { main comparisons and interactions }\end{array}$} \\
\hline & Low & Medium & High & & Trt & Parity & $\begin{array}{l}\text { Trt } \times \\
\text { parity }\end{array}$ & Week & $\begin{array}{l}\text { Trt } \times \text { parity } \\
\times \text { week }\end{array}$ \\
\hline BW, kg & 662.0 & 668.0 & 690.2 & 22 & NS & $* *$ & NS & $* *$ & $\dagger$ \\
\hline $\mathrm{BCS}$ & 3.14 & 3.23 & 3.20 & 0.07 & NS & NS & NS & $* *$ & NS \\
\hline DMI, kg/d & 23.3 & 22.0 & 22.2 & 0.88 & NS & $* *$ & NS & $* *$ & $* *$ \\
\hline \multicolumn{10}{|l|}{ Milk } \\
\hline Yield, kg/d & 36.3 & 34.7 & 36.3 & 1.37 & NS & ** & NS & ** & ** \\
\hline $3.5 \mathrm{FCM}, \mathrm{kg} / \mathrm{d}$ & 35.4 & 35.6 & 38.8 & 1.53 & NS & ** & NS & $* *$ & $* *$ \\
\hline Fat, kg/d & 1.28 & 1.28 & 1.36 & 0.071 & NS & ** & NS & ** & ** \\
\hline Protein, kg/d & 1.05 & 1.04 & 1.06 & 0.042 & NS & $* *$ & NS & $* *$ & $* *$ \\
\hline Fat, \% & 3.54 & 3.73 & 3.73 & 0.12 & NS & NS & NS & NS & NS \\
\hline Protein, \% & 2.88 & 2.94 & 2.90 & 0.04 & NS & ** & NS & $\dagger$ & NS \\
\hline FCM/DMI & 1.52 & 1.62 & 1.75 & 0.23 & NS & ** & NS & ** & NS \\
\hline $\mathrm{ME} / \mathrm{IE}^{1}$ & 0.81 & 0.89 & 0.92 & 0.05 & NS & ** & NS & $* *$ & NS \\
\hline $\mathrm{EB}^{2}$ & 9.39 & 7.48 & 6.94 & 1.37 & NS & NS & NS & $* *$ & $* *$ \\
\hline
\end{tabular}

${ }^{1} \mathrm{ME} / \mathrm{IE}=$ milk energy $(\mathrm{Mcal})$ divided by intake energy $\left(\mathrm{Mcal} \mathrm{NE}_{\mathrm{L}}\right)$.

${ }^{2} \mathrm{~EB}(\mathrm{Mcal} / \mathrm{d})=$ energy balance $=\mathrm{NE}_{\mathrm{L}}$ intake - maintenance energy - milk energy. $\mathrm{NE}_{\mathrm{L}}$ was estimated at $1.6 \mathrm{Mcal} / \mathrm{kg} \mathrm{DM}$, maintenance energy $=0.08 \times \mathrm{BW}^{.75}$, and milk energy $(\mathrm{Mcal})=\mathrm{kg}$ milk $[(0.0929 \times \% \mathrm{milk}$ fat $)+(0.0547 \times \%$ milk protein $)+0.192]$.

$\dagger P \leq 0.10$.

$* P \leq 0.05$.

$* * P \leq 0.01$

fraction. Both the cytosolic and nuclear fractions were significantly different from all other fractions. The intermediate fractions did not differ significantly from each other.

A proportion of Co in liver is associated with vitamin $\mathrm{B}_{12}$ (Underwood, 1956). Cobalt as a component of vita$\min \mathrm{B}_{12}$ has known functions within the cytosolic, mitochondrial, and nuclear fractions. Vitamin $\mathrm{B}_{12}$, as methylcobalamin, is required for methylmalonyl CoA mutase (or isomerase) activity, for conversion of methylmalonyl CoA to succinyl CoA (Baumgartner, 1983). This reaction takes place within the mitochondria (Gimsing and Nexo, 1983). N-Methyltetrahydrofolate:homocysteine methyltransferase uses the methylcobalamin form of vitamin $B_{12}$ as a coenzyme in the regeneration of methionine from homocysteine, which occurs in the cell cytoplasm (Cooper, 1983; Gimsing and Nexo, 1983). Within the nucleus, vitamin $B_{12}$ is required for enzymatic reduction of ribonucleotides and for the DNA-methylase enzyme (Schneider and Stroinski, 1987). Increased Co in ruminant diets has been reported to increase the percentage of elemental Co in liver and proportionately reduce Co associated with vitamin $\mathrm{B}_{12}$ (Underwood, 1956). The mechanism by which Co accumulates in the liver is unknown as no Co storage protein has been reported.

Experiment 2. DMI of lactating cows were affected $(P<0.05)$ by parity, week, and the interaction of treatment $\times$ parity $\times$ week of the study (Table 7). Yields of milk and 3.5 FCM also were affected by interaction of treatment $\times$ parity $\times$ week such that milk yields of multiparous cows $(42.2,43.7$, and $46.7 \mathrm{~kg}$ of $3.5 \mathrm{FCM} / \mathrm{d}$, $\mathrm{SE}=1.5$, for control, medium, and high Co treatments, respectively) were increased when fed the highest level of supplemental Co. In contrast, yields of milk and 3.5 FCM of primiparous cows $(35.8,34.9$, and $36.2 \mathrm{~kg}$ of $3.5 \mathrm{FCM} / \mathrm{d}, \mathrm{SE}=2.8$, for control, medium, and high Co treatments, respectively) were not affected, hence the threeway interaction of treatment $\times$ time $\times$ parity. Although the percent fat and the percent protein in milk was not affected by dietary treatment, yields of fat and protein also were affected by the interaction of treatment $\times$ parity $\times$ period. Milk production efficiency, calculated as milk energy/intake energy, was not affected by treatment. However, energy balance was affected by the interaction of treatment $\times$ parity $\times$ time (Table 7 ). Neither BCS nor BW was affected by dietary Co. Concentrations of glucose and NEFA in serum were unaffected by dietary treatments (Table 8). Serum concentrations of glucose were lowest at the early postpartum sampling periods and serum NEFA levels were much higher at seven DIM than at $21 \mathrm{~d}$ prepartum or 120 DIM (Table 9).

Concentrations of $\mathrm{Co}, \mathrm{Cu}, \mathrm{Zn}$, and $\mathrm{Mn}$ in colostrum and milk were not affected by dietary treatments (Table 10). However, primiparous cows had significantly higher concentrations of Co in colostrum (0.119 vs. $0.093 \mu \mathrm{g} / \mathrm{ml}$, respectively) and milk (0.099 vs. 0.082 $\mu \mathrm{g} / \mathrm{ml}$, respectively) compared with multiparous cows. 
Table 8. Effect of dietary Co supplementation on the concentration of trace elements in serum, whole blood, and liver of lactating cows (Study 2).

\begin{tabular}{|c|c|c|c|c|c|c|c|c|c|}
\hline & \multicolumn{3}{|c|}{ Treatment } & \multirow[b]{2}{*}{$\mathrm{SE}$} & \multicolumn{5}{|c|}{$\begin{array}{l}\text { Type II SS } P>F \text { for } \\
\text { main comparisons and interactions }\end{array}$} \\
\hline & Low & Med & High & & Trt & Parity & $\begin{array}{l}\text { Trt } \times \\
\text { parity }\end{array}$ & Week & $\begin{array}{l}\text { Trt } \times \text { parity } \\
\times \text { week }\end{array}$ \\
\hline \multicolumn{10}{|l|}{ Serum } \\
\hline $\mathrm{Co}, \mathrm{mg} / \mathrm{kg}$ & 0.10 & 0.096 & 0.094 & 0.0012 & NS & NS & NS & $* *$ & NS \\
\hline $\mathrm{Cu}, \mathrm{mg} / \mathrm{kg}$ & 0.62 & 0.68 & 0.70 & 0.027 & NS & NS & NS & $* *$ & $\dagger$ \\
\hline $\mathrm{Zn}, \mathrm{mg} / \mathrm{kg}$ & 1.07 & 1.00 & 0.93 & 0.058 & NS & $* *$ & NS & $* *$ & $* *$ \\
\hline $\mathrm{Fe}, \mathrm{mg} / \mathrm{kg}$ & 2.36 & 2.37 & 2.39 & 0.14 & NS & NS & NS & NS & NS \\
\hline $\mathrm{B}_{12}, \mathrm{ng} / \mathrm{ml}$ & 1.89 & 2.23 & 1.46 & 0.415 & NS & $* *$ & NS & $*$ & NS \\
\hline Glucose, mg/dl & 66.2 & 67.6 & 70.9 & 2.67 & NS & NS & NS & $\dagger$ & NS \\
\hline $\mathrm{NEFA}, \mathrm{mEg} / \mathrm{L}$ & 0.95 & 1.10 & 1.14 & 0.26 & NS & NS & NS & $* *$ & NS \\
\hline \multicolumn{10}{|l|}{ Whole Blood } \\
\hline $\mathrm{Co}, \mu \mathrm{g} / \mathrm{ml}$ & 0.108 & 0.097 & 0.096 & 0.002 & NS & NS & NS & ** & NA \\
\hline $\mathrm{Mn}, \mu \mathrm{g} / \mathrm{ml}$ & 0.196 & 0.171 & 0.194 & 0.013 & NS & NS & NS & $* *$ & NS \\
\hline $\mathrm{PCV}^{1}, \%$ & 33.0 & 32.4 & 33.8 & 0.38 & NS & NS & NS & $*$ & NS \\
\hline \multicolumn{10}{|l|}{ Liver $^{2}$} \\
\hline $\mathrm{Co}, \mathrm{mg} / \mathrm{kg}$ & 2.19 & 2.50 & 1.28 & 0.17 & $*$ & NS & NS & NA & NA \\
\hline $\mathrm{Zn}, \mathrm{mg} / \mathrm{kg}$ & 40.0 & 41.6 & 40.8 & 4.15 & NS & NS & NS & NA & NA \\
\hline
\end{tabular}

${ }^{1} \mathrm{PCV}=$ packed cell volume

${ }^{2}$ Wet-weight basis.

$\dagger P \leq 0.10$.

$* P \leq 0.05$.

$* * P \leq 0.01$.

Copper in colostrum, but not milk, was affected by the interaction of treatment $\times$ parity.

There were no effects of dietary treatment on concentrations of $\mathrm{Co}, \mathrm{Cu}, \mathrm{Zn}$, and $\mathrm{Mn}$ in serum (Table 8). There was a period effect such that Co concentrations in serum were highest at seven DIM and were subsequently lowest by 120 DIM (Table 9), perhaps indicating that secretion of Co into milk was a drain on endogenous Co reserves. Mean concentrations of Co in serum and whole blood were quite close $(0.095 \mu \mathrm{g}$ Co per milliliter of serum and $0.098 \mu \mathrm{g}$ Co per milliliter of whole blood). Although Co concentrations in whole blood (0.105 vs. $0.096 \mu \mathrm{g} / \mathrm{ml})$ and serum (0.099 vs. $0.094 \mu \mathrm{g} / \mathrm{ml})$ were numerically higher in primiparous than multiparous cows, overall, there was not a parity effect because Co

Table 9. Effect of days-in-milk on selected measures in serum of lactating cows (Study 2).

\begin{tabular}{llccl}
\hline & \multicolumn{3}{c}{ Days in milk } \\
\cline { 2 - 4 } Serum & -21 & 7 & 120 & SE \\
\hline Glucose, mg/dl & 72 & 62 & 71 & 2.6 \\
NEFA, mEq/dl & 0.473 & 1.90 & 0.64 & 0.15 \\
$\mathrm{Co}, \mu \mathrm{g} / \mathrm{ml}^{\mathrm{a}}$ & 0.099 & 0.116 & 0.075 & 0.006 \\
$\mathrm{~B}_{12}, \mathrm{ng} / \mathrm{ml}^{\mathrm{ab}}$ & 2.356 & 1.984 & 1.235 & 0.229 \\
$\mathrm{Zn}, \mu \mathrm{g} / \mathrm{ml}^{\mathrm{abc}}$ & 1.14 & 1.06 & 0.88 & 0.04 \\
$\mathrm{Cu}, \mu \mathrm{g} / \mathrm{ml}^{\mathrm{a}}$ & 0.65 & 0.72 & 0.71 & 0.027 \\
\hline
\end{tabular}

a Significant effect of time, $P<0.05$.

${ }^{\mathrm{b}}$ Significant effect of parity, $P<0.05$.

${ }^{\mathrm{c}}$ Significant interaction of treatment $\times$ parity $\times$ time, $P<0.05$. concentrations in serum of primiparous cows declined sharply from 7 to 120 DIM. Similar to changes in Co concentrations in serum, there were significant effects of period on concentrations of $\mathrm{Cu}$ and $\mathrm{Zn}$ in serum (Table 9). The concentrations of $\mathrm{Zn}$ in liver were similar among treatments (Table 8).

Cobalt supplementation did not increase Co in the liver, in fact, concentrations of Co in liver were reduced in cows fed the high Co diets (Table 8). Cobalt absorption and tissue retention are very low in ruminants. By use of ${ }^{60} \mathrm{Co}$, Looney et al. (1976) estimated 95 to $98 \%$ of ${ }^{60} \mathrm{Co}$ given orally to sheep was excreted via the feces within $5 \mathrm{~d}$, and a further 0.5 to $2.0 \%$ was excreted via the urine. Therefore, supplementation of cows in the current study with 15 to $30 \mathrm{mg}$ of Co per day was unlikely to increase tissue Co significantly within $140 \mathrm{~d}$. Henry et al. (1997) and Kawashima et al. (1997) found significant increases of Co in liver of sheep fed supplemental Co; however, they fed diets supplemented with much higher Co levels (20 and $40 \mathrm{mg} / \mathrm{kg} \mathrm{Co}$ ). Furthermore, if Co retention is only $2 \%$ of intake, and Co intake averaged 9,16 , and $30 \mathrm{mg} / \mathrm{d}$ for the three treatment groups, then cows were in negative Co balances of about $3.1,3.0$, and $2.7 \mathrm{mg} / \mathrm{d}$, respectively, due to Co secretion into milk (Table 10). Although intestinal absorption of Co may have been greater than $2 \%$, it would need to have been at least $37 \%$ in control cows to maintain a positive Co balance relative to intake and milk secretion of Co. Although concentrations of $\mathrm{Co}$ in liver in primipa- 
rous and multiparous cows ( $2.16 \mathrm{vs} .1 .82 \mu \mathrm{g} / \mathrm{g}$ ) were not significantly different, the liver samples were taken after 120 DIM and substantial losses of Co from liver for milk secretion may have already occurred. Unfortunately, prepartum concentrations of Co in liver were not measured. However, because a metabolic role for Co that is separate from vitamin $B_{12}$ is unknown, a negative Co balance may not be harmful to cattle if enough $B_{12}$ is synthesized in the rumen to meet needs for metabolism, lactation, and gestation.

There was no effect of Co supplementation on concentrations of vitamin $\mathrm{B}_{12}$ in serum of cows (Table 8). However, there was a significant effect of week and a significant interaction of parity $\times$ week on serum $B_{12}$ concentrations (Figure 3 and Table 9). Primiparous cows had higher $\mathrm{B}_{12}$ concentrations in serum than multiparous cows ( 1.81 vs. $0.96 \mathrm{ng} / \mathrm{ml})$. Also, serum $\mathrm{B}_{12}$ concentrations declined from $2.4 \mathrm{ng} / \mathrm{ml}$ at $21 \mathrm{~d}$ prepartum, to $2.0 \mathrm{ng} / \mathrm{ml}$ at seven DIM, to $1.2 \mathrm{ng} / \mathrm{ml}$ at $120 \mathrm{DIM}$. Elliot et al. (1965) previously reported that $\mathrm{B}_{12}$ in blood is reduced in early lactation cows. Reduced blood $\mathrm{B}_{12}$ may be caused by a combination of maternal transfer of $\mathrm{B}_{12}$ to the fetus, colostrum, and milk, and by restricted roughage diets in cows (Walker and Elliot, 1972).

An explanation why lactating primiparous and multiparous cows responded differently to Co supplementation is not clear. There are at least three possible modes of action by which Co could affect ruminant production. First, increased ruminal synthesis and subsequent absorption of vitamin $\mathrm{B}_{12}$ with added dietary $\mathrm{Co}$; second, supplemental Co could increase ruminal fermentation, possibly by an increased vitamin $B_{12}$ supply to bacterial strains that do not synthesize $\mathrm{B}_{12}$; and third, there may be a possible metabolic role for Co. Results of experiment 1 indicated that endogenous reserves of Co were different between young (2.5 yr) and old (6.5 yr) cows.

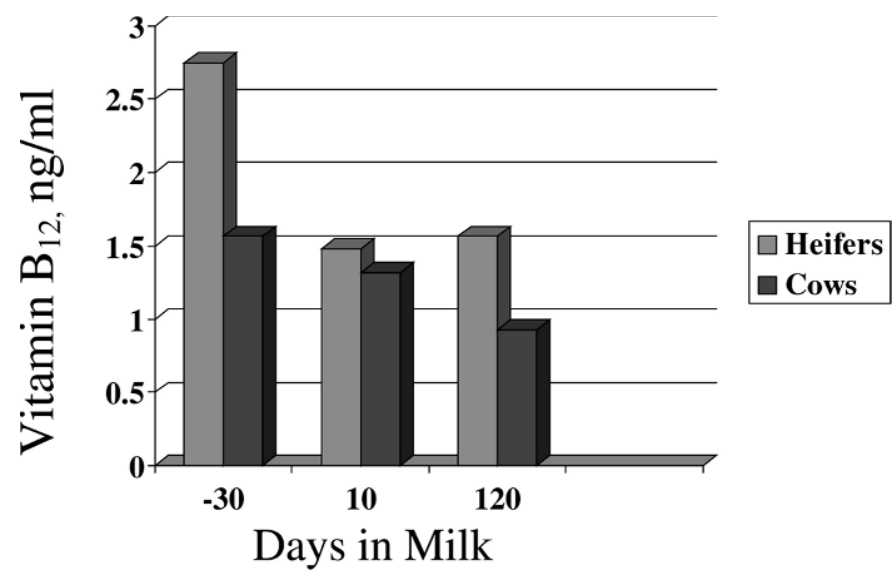

Figure 3. Effect of parity and days in milk on concentration of vitamin $B_{12}$ in serum, study $2 . \mathrm{SE}=0.415 \mathrm{ng} / \mathrm{ml}$.
In experiment 2 , primiparous cows at parturition had higher status of Co and vitamin $\mathrm{B}_{12}$, as evidenced by higher Co concentrations in serum, colostrum, milk and higher $\mathrm{B}_{12}$ in serum than did multiparous cows. Concentrations of vitamin $\mathrm{B}_{12}$ and $\mathrm{Co}$ in serum decreased in all cows during lactation; thus, milk secretion appeared to be a substantial drain on endogenous reserves of both Co and vitamin $B_{12}$.

A net balance for vitamin $B_{12}$ was not calculated for cows in this trial because total daily ruminal synthesis and intestinal absorption of vitamin $B_{12}$ was not known. Normal concentrations of $\mathrm{B}_{12}$ in milk are 2 to $4 \mu \mathrm{g} / \mathrm{L}$ (Puls, 1988); thus, daily secretion of $\mathrm{B}_{12}$ into milk was probably between 72 and $144 \mu \mathrm{g} / \mathrm{d}$. Blood concentrations of vitamin $\mathrm{B}_{12}$ were depressed during the initial 120 DIM, indicating $\mathrm{B}_{12}$ absorption probably was less than need for $\mathrm{B}_{12}$, including secretion into milk. Because milk secretion represents such a large output of vitamin $\mathrm{B}_{12}$ and $\mathrm{Co}$, replenishment of endogenous reserves of these nutrients needs to occur largely during the dry period, however, and their intestinal absorption is low.

Experiment 3. Average daily feed intakes were greater $(P<0.01)$ for calves fed the control starter $(1.79$ vs. $1.62 \mathrm{~kg} / \mathrm{d}$, respectively, $\mathrm{SE}=0.06)$. During the 12 wk period, average intakes of Co were $1.13 \mathrm{mg} / \mathrm{d}$ for the unsupplemented calves and $2.17 \mathrm{mg} / \mathrm{d}$ for the calves consuming the starter supplemented with cobalt. If a value of $0.09 \mathrm{mg}$ Co per kilogram of milk is assumed (Table 10), the calves consumed about $0.2 \mathrm{mg}$ Co per day for the first 4 wk and about $0.1 \mathrm{mg}$ of Co per day during wk 5 and 6 from the milk. Average daily gains $(0.74 \mathrm{~kg} / \mathrm{d})$ were similar $(P>0.05)$ for calves fed either starter.

Calves fed the control starter had higher concentrations of Co in serum than calves fed the Co-supplemented starter. The reason for this is unclear. Calves of primiparous dams had a tendency $(P=0.14)$ for higher serum Co concentrations than calves of multiparous cows. Week of treatment had a significant effect on serum Co concentrations $(P<0.01)$ with increased serum Co concentrations at wk 6 of treatment followed by a decline at wk 12 . This may be due, at least in part, to absorption of Co from the milk, or possibly reflect higher intestinal absorption efficiency of Co in preweaned calves.

Cobalt concentration in liver was not affected by either Co supplementation $(P>0.05)$ or the age of calf's dam $(P>0.05)$. Calves fed the Co-supplemented diet had average liver Co concentrations of $5.18 \mathrm{mg} / \mathrm{kg}$ (wt/ wt) compared with $4.26 \mathrm{mg} / \mathrm{kg}$ (wt/wt) in calves fed the control starter. Concentrations of Co in serum and liver were poorly correlated $(\mathrm{r}=0.28)$ although correlations were somewhat higher within treatment groups $(r=$ 
Table 10. Effect of dietary cobalt supplementation on the concentration of trace elements in colostrum and milk (Study 2).

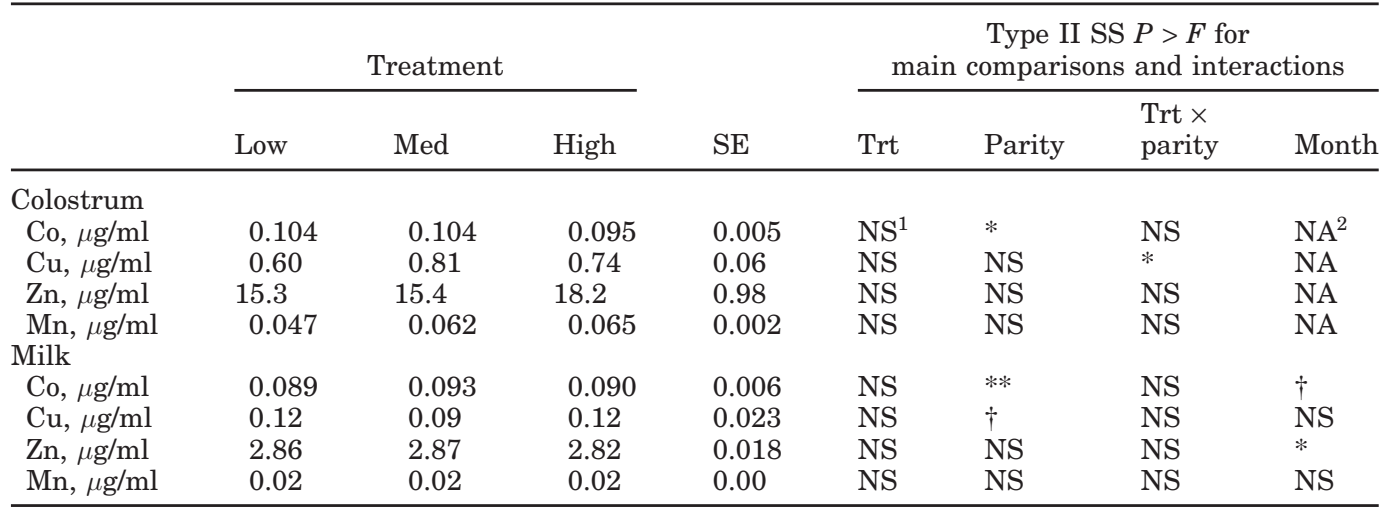

${ }^{1} \mathrm{NS}=$ not significant, $P>0.10$.

${ }^{2} \mathrm{NA}=$ not applicable.

$\dagger P \leq 0.10$.

$* P \leq 0.05$.

$* * P \leq 0.01$.

0.42 for control calves and $\mathrm{r}=0.53$ for Co-supplemented calves). The concentrations of Co in liver of the calves in this study are much higher than the Co concentrations in liver of Holstein cows in experiments 1 and 2. Thus, Co concentration in liver appears to decline with age in dairy cattle.

Concentrations of Co in whole blood did not differ $(P$ $>0.05$ ) between treatment groups. Cobalt concentration in whole blood was lower than in serum at wk 0 and 6 for calves consuming the unsupplemented starter but greater than serum cobalt concentration at wk 12 and in the calves consuming the supplemented starter. This may be due to greater variation of Co concentrations in serum than erythrocytes (Young, 1979).

Rumen fluid of calves was analyzed for VFA as an indication of effects on ruminal fermentation. Previously, Allen (1986) reported $10 \mathrm{mg} / \mathrm{kg}$ dietary Co increased cellulose digestibility in vitro of diets containing $40 \%$ forage, $60 \%$ concentration. Likewise, Co supplementation may increase propionate production by certain ruminal bacteria that are dependent upon vitamin $\mathrm{B}_{12}$ in order to convert succinate to propionate (Strobel, 1992). However, there was no effect $(P>0.05)$ of Co supplementation on the ratio of acetate to propionate in ruminal fluid of calves at $12 \mathrm{wk}$ of age. Average molar concentrations of propionate in ruminal fluid were 49.6 and $50.8 \mu \mathrm{m} / \mathrm{L}(\mathrm{SE}=1.21)$ for control and supplemented calves, respectively. The concentration of acetate in ruminal fluid was 65.0 and $72.8 \mu \mathrm{m} / \mathrm{L}$ (SE $=1.00$ ), respectively, for calves fed the control and Cosupplemented starter.

The decline in concentration of Co in liver of cattle with age is not entirely unique among trace elements; in fact, metabolism of Co has several similarities to chromium metabolism. Chromium concentration declines in most tissues (except lungs) as animals age (Anderson, 1987). In a manner similar to $\mathrm{Co}, \mathrm{Cr}^{+3}$ also is poorly absorbed ( 0.5 to $2 \%$ ) and is probably transported using Fe-binding proteins in blood (Offenbacher et al., 1997). In addition, the biologically active forms of Co (vitamin $\mathrm{B}_{12}$ ) and $\mathrm{Cr}$ (glucose tolerance factor) are organic complexes, and there is no known biological activity for either inorganic element.

\section{CONCLUSIONS}

The concentration of Co in serum, whole blood, liver and subcellular distribution of Co in liver of cattle was not affected by Co supplementation in these studies. Within liver, nearly $40 \%$ of the Co was present in the cytoplasm. The concentration of Co in liver did not affect the subcellular distribution of Co. Age of the animal affected the concentration of Co in liver with the highest concentrations in young calves and higher concentrations in younger than older cows. The decline of Co in liver with age of cattle may be due to a combination of low intestinal absorption, endogenous losses, and Co secretion into milk. However, no effects due to loss of Co from liver with age are known. Thus, further research appears to be needed on the effects of Co supplementation on ruminal fermentation and metabolism of dairy cattle.

\section{REFERENCES}

Allen, M. 1986. Effects of cobalt supplementation on carbohydrate and nitrogen utilization by ruminal bacteria in continuous culture. M.S. Thesis. Univ. Minnesota, St. Paul. 
Anderson, R. A. 1987. Chromium in Trace Elements in Human and Animal Nutrition, 5th ed. W. Mertz, ed. Academic Press, Inc., New York, NY.

Association of Official Analytical Chemists. 1990. Official Methods of Analysis. Vol. 1. 15th ed. AOAC, Arlington, VA.

Baumgartner, R. 1983. Activity of the cobalamin-dependent methylmalonyl-CoA mutase. Pages 181-195 in Methods in Hematology: The Cobalamins. C. H. Hall, ed. Churchill Livingstone, New York, NY.

Chen, C. Y., P. Zhang, X. L. Hou, and Z. Chai. 1999. Investigation of selenium distribution in subcellular fractions of human liver by neutron activation analysis. Biol. Trace Elem. Res. 7172:131-138.

Cooper, B. A. 1983. The assay of cobalamin-dependent enzymes: Their utilization for evaluation of cobalamin metabolism. Pages 165180 in Methods in Hematology: The Cobalamins. C. H. Hall, ed. Churchill Livingstone, New York, NY.

Dryden, L. P., and A. M. Hartman. 1971. Variations in the amount and relative distribution of vitamin $\mathrm{B}_{12}$ and its analogs in the bovine rumen. J. Dairy Sci. 54:235-246.

Elliot, J. M., E. P. Barton, and J. A. Williams. 1979. Milk fat as related to vitamin $\mathrm{B}_{12}$ status. J. Dairy Sci. 62:642-645.

Elliot, J. M., D. E. Hogue, and H. F. Tyrrell. 1965. Blood vitamin $B_{12}$ status of the dairy cow in late pregnancy and early lactation. J. Dairy Sci. 48:1335-1338

Gimsing, P., and E. Nexo. 1983. The forms of cobalamin in biological materials. Pages 7-30 in Methods in Hematology: The Cobalamins. C. H. Hall, ed. Churchill Livingstone, New York, NY.

Henry, P. R., R. C. Littell, and C. B. Ammerman. 1997. Bioavailability of cobalt sources for ruminants. 1. Effects of time and dietary cobalt concentration on tissue cobalt concentration. Nutr. Res. 17:947-955.

Kawashima, T., P. R. Henry, C. B. Ammerman, R. C. Littell, and J. Price. 1997. Bioavailability of cobalt sources for ruminants. 2. Estimation of the relative value of reagent grade and feed grade cobalt sources from tissue cobalt accumulation and vitamin $\mathrm{B}_{12}$ concentrations. Nutr. Res. 17:957-974.

Looney, J. W., G. Gille, R. L. Preston, E. R. Graham, and W. H. Pfander. 1976. Effects of plant species and cobalt intake upon cobalt utilization and ration digestibility by sheep. J. Anim. Sci. 42:693-698.

McDowell, L. R. 1992. Minerals in Animal and Human Nutrition. Academic Press, Inc., San Diego, CA.

Mills, C. F. 1981. Cobalt deficiency and cobalt requirements of ruminants. Pages 129-140. In: W. Haresign, Ed. Recent Advances in Animal Nutrition. Butterworths, Boston, MA.

National Research Council. 2001. Nutrient Requirements of Dairy Cattle. 7th rev. ed. Natl. Acad. Sci., Washington, DC.

Offenbacher, E. S., F. X. Pi-Sunyer, and B. J. Stoecker. 1997. Chromium in Handbook of Nutritionally Essential Mineral Elements. B. L. O'Dell and R. A. Sunde, eds. Marcel Dekker, Inc., New York, NY.

Puls, R. 1988. Mineral Levels in Animal Health. Trinity Western University Press. British Columbia, Canada.

Robinson, J. W. 1975. Atomic Absorption Spectroscopy, 2nd edition. Marcel Dekker, Inc., New York, NY.

SAS. User's Guide, Version 8.1, 1st edition. SAS Inst. Inc., Cary, NC.

Schneider, Z. and A. Stroinski. 1987. Comprehensive $B_{12}$. Walter deGruyter Inc. Hawthorne, NY.

Smith, R. M. and H. R. Marston. 1970. Production, absorption, distribution, and excretion of vitamin $\mathrm{B}_{12}$ in sheep. Brit. J. Nutr. 24:857-867.

Strobel, H. J. 1992. Vitamin $\mathrm{B}_{12}$-dependent propionate production by the ruminal bacterium Prevotella ruminicola 23. Appl. Environ. Microbiol. 58:2331-2333.

Sutton, A. L., and J. M. Elliot. 1972. Effect of ratio of roughage to concentrate and level of feed intake on ovine ruminal vitamin $\mathrm{B}_{12}$ production. J. Nutr. 102:1341-1346.

Underwood, E. J. 1956. Trace Elements in Human and Animal Nutrition. Academic Press, Inc. New York, NY.

Underwood, E. J., and N. F. Suttle. 1999. Cobalt in: The Mineral Nutrition of Livestock. CABI Publishing, New York, NY.

Walker, C. K., and J. M. Elliot. 1972. Lactational trends in vitamin $\mathrm{B}_{12}$ status on conventional and restricted-roughage rations. J. Dairy Sci. 55:474-479.

Wapnir, R. A. 1990. Protein Nutrition and Mineral Absorption. CRC Press, Inc., Boca Raton, FL.

Young, R. S. 1979. Cobalt in Biology and Biochemistry. Academic Press, Inc., San Francisco, CA. 